\title{
MANUFACTURING ENGINE TEST BED DLE-55CC SINGLE CYLINDER PETROL
}

\author{
Siti Iin Infitah Hilmiah ${ }^{1}$, Sri Mulyani², Lazuardy Rahendra $\mathbf{P}^{3}$ \\ Teknik Dirgantara, Institut Teknologi Dirgantara Adisutjipto \\ tiafitahilmiah274@gmail.com, srimulyani042@gmail.com, lazuardyrp@itda.ac.id
}

\begin{abstract}
The engine test bed is a tool used for testing in the development of new aircraft when it is installed into the aircraft to determine the capabilities of each engine. This engine test bed research aims to meet the needs of the learning process in supporting the practicum. By determining the geometry, modeling, material selection, manufacture, and testing of the engine test bed it will be known that the engine performance is good before use. The method used is a practical and analytical method to analyze the data that has been obtained from the test. The object of research used in this study is a dle-55cc engine. based on the results of testing the results of the thrust that compares with the static value of the thrust calculator, the average difference is obtained. From the results of the comparison of errors on the test equipment, the $22 \times 8$ propeller $(4.5 \mathrm{~cm}$ chord) obtained an average error of $4.178 \%$. While the propeller $22 \times 8$ (chord $5 \mathrm{~cm}$ ) the error generated is $3.719 \%$ and from the value of fuel consumption obtained it produces 588,600-20,708 (N/kW.hr) this shows a good level of decline, so the engine used is more efficient in its use. From the test results, it can be said that the engine test bed has accuracy and can produce good engine performance to be used as a testing and other learning tool.
\end{abstract}

Keywords: Engine test bed, Propeller, Thrust

\section{Pendahuluan}

Engine adalah komponen dari sistem propulsi untuk pesawat terbang yang menghasilkan tenaga mekanik. Sistem propulsi berfungsi menghasilkan gaya dorong pada pesawat terbang sehingga pesawat terbang dapat bergerak mencapai kecepatan tertentu[1]. Engine test bed merupakan alat pengujian dalam pengembangan mesin pesawat baru ketika dipasang ke pesawat untuk mengetahui kemampuan dari setiap engine dengan tujuan agar dapat memastikan apakah engine memiliki performa yang baik sebelum digunakan pada pesawat [2]. Selain itu penggunaan engine test bed dapat digunakan untuk proses pembelajaran dalam menunjang kegiatan praktikum propulsi khususnya di kampus, maka dalam hal ini dibutuhkan adanya alat uji untuk membantu proses pemilihan sistem propulsi maupun pembelajaran dengan kebutuhan yang diperlukan, sehingga kedepannya dapat bermanfaat.

Berdasarkan uraian diatas untuk membantu proses pembelajaran dan mengetahui performa engine. Maka penelitian ini akan membahas mengenai manufaktur engine test bed dle-55cc single cylinder petrol. Manufaktur merupakan proses mengubah bahan baku menjadi produk melalui bermacam-macam proses mesin dan operasional mengikuti perencanaan yang terorganisasi dengan baik. Proses manufaktur terbagi dalam beberapa proses yaitu Perancangan produk, Pemilihan material dan Tahap-tahap pembuatan produk[3]. Pembuatan produk dilakukan sesuai dengan desain yang telah dilakukan pada software CATIA. Setelah dilakukan pembuatan selanjutnya yaitu melakukan proses pengujian dan pengumpulan data pada alat uji tersebut untuk mengetahui performa dari engine dle-55cc dengan menghitung nilai thrust dan konsumsi bahan bakar. Gaya Dorong atau thrust adalah hasil dari perputaran propeller yang mengubah daya perputaran mesin menjadi gaya dorong. selama pesawat tidak bergerak, propeller beroperasi dalam kondisi statik. tidak ada aliran udara masuk menuju propeller yang 
membuat gerakan arus masuk sendiri. Propeller memiliki koefisien gaya dorong yang merupakan perbandingan maksimum gaya dorong yang dihasilkan oleh mesin pesawat terhadap berat total pesawat. Pada umumnya perbandingan gaya dorong terhadap beban berdasarkan dari aturan pengalaman para desainer pesawat. Referensi ini diperoleh dari hasil desain pesawat sebelumnya. Kesepakatan tersebut menyatakan bahwa gaya dorong statik mampu membawa pesawat hingga kondisi jelajah (cruise) dan menanjak (climb) pada minimal satu banding tiga (1:3) total berat pesawat. [4]Dasar teori yang digunakan adalah hukum Newton 2 dan 3. hukum Newton juga menyatakan bahwa gaya sebandinng dengan perubahan momentum adalah masa dikali dengan kecepatan $(m \cdot v)$. dalam beberapa kasus, massa tetap konstan, sehingga diperoleh gaya.

$$
F=\frac{d(m v)}{d t}=\frac{m d v}{d t}=m a
$$

Persamaan nomor 1 adalah bunyi hukum Newton ke-2 untuk massa yang konstan, jika kita dapat mengukur percepatan dari setiap molekul udara yang dipercepat, maka gaya dorong yang dihasilkan dari setiap molekul udara akan menjadi massa molekul udara dikali percepatan molekul udara. Total gaya dorong dari propeller adalah jumlah dari individu gaya dorong setiap molekul. pendekatan selanjutnya adalah jika kecepatan konstan dan massa yang berubah. kecepatan dari masing-masing molekul yang konstan akan menjadi:

$$
F=\frac{d(m v)}{d t}=\left(\frac{d m}{d t}\right) v=m v
$$

Untuk pesawat statik, kecepatan molekul udara yang melewati propeller akan berpengaruh terhadap gaya dorong jika massa molekul dianggap tetap dan mempercepat kecepatan. Oleh karena itu, gaya dorong propeller $\mathrm{F}$ untuk pesawat statik adalah:

$$
F=m V_{e}
$$

Sedangkan untuk pesawat yang bergerak kecepatan udara yang dipercepat oleh propeller berpengaruh terhadap gaya dorong. sehingga persamaan untuk gaya dorong yang dinamis diperoleh:

$$
F=\rho \frac{\pi d^{2}}{4}\left(V_{e}^{2}-V_{e} V_{a c}\right)
$$

Sedangkan hukum Newton ke-3 adalah reaksi. Propeller menghasilkan gaya dorong dengan cara mempercepat molekul udara. $V_{e}$ adalah kecepatan udara keluar melewati propeller , $V_{a c}$ adalah kecepetan pesawat, $\mathrm{F}$ adalah gaya dorong, $\rho$ adalah densitas udara, $\mathrm{d}$ adalah diameter propeller. $V_{e}$ diasumsikan mendekati sama dengan kecepatan propeller

$$
V_{\text {pitch }}(\mathrm{mph})=R P M_{\text {prop }} \cdot \text { Pitch }_{\text {prop }}(\text { in }) \cdot \frac{1 \mathrm{ft}}{12 \mathrm{in}} \cdot \frac{1 \mathrm{mile}}{5280 \mathrm{ft}} \cdot \frac{60 \mathrm{~min}}{\mathrm{hr}}
$$

$\mathrm{R}$ adalah konstanta spesifik gas di udara $287 \mathrm{~J} /(\mathrm{kg} * \mathrm{~K})$, dan $\rho=1.225 \mathrm{~kg} / \mathrm{m} 3$. sehingga jika subtitusi rumus diatas ke persamaan (4) akan diperoleh persamaan teoritikal statik gaya dorong

$$
F=1.225 \frac{\pi(0.0254 \cdot d)^{2}}{4}\left(R P M_{\text {prop }} \cdot \text { pitch } \cdot \frac{1 \text { min }}{60 s e c}\right)^{2}
$$

Dari perumusan teoritik tersebut, diketahui bahwa gaya dorong yang dihasilkan mesin dapat dirumuskan dengan mengetahui berapa rpm, pitch dan diameter propeller [5].

Dimana:

$$
F=\rho \frac{\pi(0.0254 \cdot d)^{2}}{4}\left(R P M_{\text {prop }} \cdot \text { pitch } \cdot \frac{1 \mathrm{~min}}{60 \mathrm{sec}}\right)^{2}
$$

F: Static thrust (newton)

$\rho$ : Kerapatan udara $\left(\mathrm{kg} / \mathrm{m}^{3}\right)$

$\mathrm{d}$ : Diameter propeller (inch) 
Konsumsi bahan bakar (Fuel consumption) adalah jumlah bahan bakar per waktunya atau ukuran ekonomi pemakaian bahan bakar[6]. Konsumsi bahan bakar dihasilkan sebagai bahan bakar laju aliran per jam, sedangkan dalam engineering practice konsumsi bahan bakar dinyatakan sebagai specific Fuel consumption (SFC) didefinisikan sebagai berikut:

$$
S F C=\frac{\text { Fuel Flow Rate }\left(\frac{N}{j a m}\right)}{B H P(k W)} \quad(\mathrm{N} / \mathrm{jam} . \mathrm{kW})
$$

Dimana:

Fuel Flow Rate = laju aliran bahan bakar (N/jam)

BHP $\quad=$ output dari mesin sebagai tenaga di poros mesin $(\mathrm{kW})$

Untuk membedakan konsumsi bahan bakar specifik dari piston atau mesin turboprop didefinisikan sebagai berikut:

$$
B S F C=\frac{\text { Fuel Flow Rate }\left(\frac{N}{j a m}\right)}{B H P(k W)} \quad(\mathrm{N} / \mathrm{jam} . \mathrm{kW})
$$

\section{Metode Penelitian}

Penelitian dilakuan dengan dua metode yaitu metode praktik dan analitik. Penelitian dilakukan dengan melakukan pengujian statik gaya dorong engine menggunakan engine test bed yang sebelumnya sudah dimanufaktur di laboratorium. Untuk mengukur gaya dorong engine dilakukan dengan menggunakan load cell, Keluaran load cell diberikan pada display box. Setelah diperoleh itu dilakukan pengujian pada engine. Pengujian engine ini dilakukan menggunakan engine test bed dengan mencari nilai bahan bakar yang diperoleh dan mencari nilai thrust menggunakan sensor, sensor ini ditempatkan sejajar dengan dudukan mesin pada meja uji, agar hasil pengukuran gaya dorong mesin yang didapat maksimum. Metode kedua dilakukan perhitungan menggunakan static thrust calculator dengan membandingkan besarnya gaya dorong yang diperoleh secara perhitungan, alat uji ini dirancang dan dibuat untuk mengetahui performa dari engine dle-55cc. data eksperimental dikumpulkan dan di plot terhadap data static thrust calculator dari 2 jenis propeller wood dengan ukuran $22 \times 8$ (chord $4,5 \mathrm{~cm}$ dan chord $5 \mathrm{~cm}$ ) dan data konsumsi bahan bakar yang digunakan. Pengujian dilakukan pada kecepatan 1500-7000 rpm dibawah kondisi pengujian lingkungan yang sama. Sebelum melakukan pengujian pastikan seluruh komponen alat yang digunakan pada pengujian bekerja dengan baik, tujuan dilakukan pengujian untuk membuat alat uji yang handal dari suatu engine.

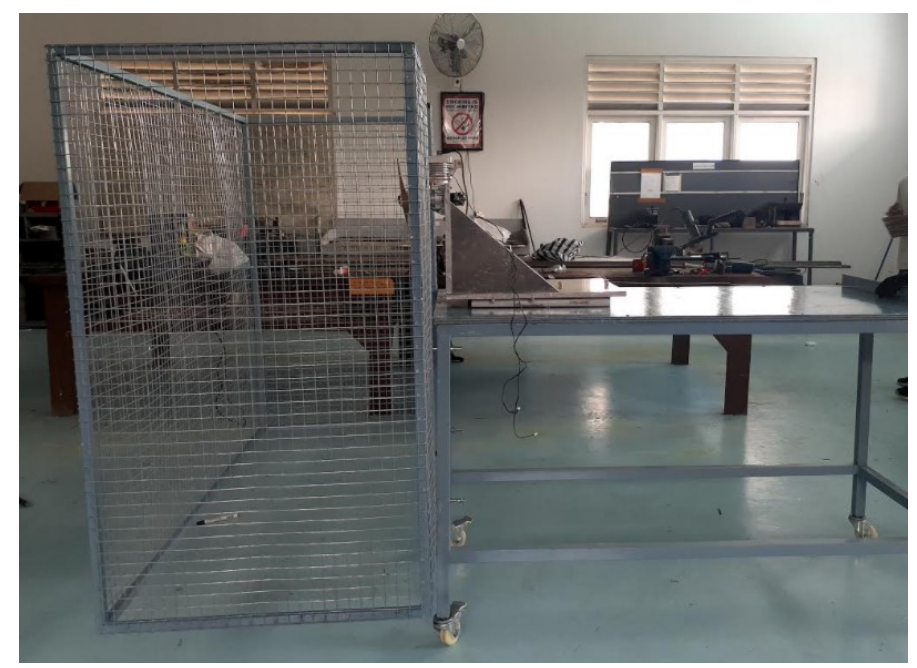

Gambar 1. Engine Test Bed 
Pengujian fuel consumption dilakukan untuk mengetahui konsumsi bahan bakar dari engine dle-55cc yang digunakan pada setiap pengujian dengan variasi 1500-7000 rpm. Hasil pengujian kecepatan rotasi dan fuel consumption sebagai berikut:

Tabel 1 Hasil Pengujian Fuel consumption

\begin{tabular}{|c|c|c|c|c|c|c|}
\hline \multirow{2}{*}{$\begin{array}{c}\text { VARIABEL } \\
\text { RPM }\end{array}$} & $\begin{array}{c}\text { RPM } \\
G T\end{array}$ & \multirow{2}{*}{ RPM } & \multicolumn{3}{|c|}{ FUEL CONSUMPTION (g/minute) } & \multirow{2}{*}{ RATA-RATA } \\
\cline { 4 - 7 } & POWER & & \multicolumn{2}{|c|}{} & & \\
\cline { 4 - 7 } & & Pengujian 1 & Pengujian 2 & Pengujian 3 & (g/minute) \\
\hline 1500 & 1517 & 1490 & 29 & 31 & 30 & 30 \\
\hline 3000 & 3100 & 3059 & 34 & 35 & 36 & 35 \\
\hline 4500 & 4584 & 4535 & 45 & 45 & 44 & 75 \\
\hline 6000 & 6113 & 6005 & 71 & 73 & 75 & 112 \\
\hline 7000 & 6987 & 6973 & 112 & 111 & 112 & \\
\hline
\end{tabular}

Pengujian engine dengan propeller dilakukan untuk mengetahui nilai thrust dari engin dle$55 \mathrm{cc}$ yang digunakan pada setiap pengujian dengan variasi 1500-7000 rpm. Hasil pengujian kecepatan rotasi dan fuel consumption sebagai berikut:

Tabel 2. Pengujian Engine Dengan Propeller $22 \times 8$ (chord 4,5cm)

\begin{tabular}{|c|c|c|c|c|c|c|c|c|}
\hline \multirow{2}{*}{$\begin{array}{c}\text { VARIABEL } \\
\text { RPM }\end{array}$} & \multirow{2}{*}{$\begin{array}{l}\text { RPM GT } \\
\text { POWER }\end{array}$} & \multirow{2}{*}{$\begin{array}{c}\text { RPM } \\
\text { TACHO }\end{array}$} & \multirow{2}{*}{$\begin{array}{c}\text { T. SPOOL } \\
\frac{\left({ }^{\circ} \mathrm{C}\right)}{}\end{array}$} & \multirow{2}{*}{\begin{tabular}{|c|} 
T.CRANKCASE \\
$\left({ }^{\circ} \mathrm{C}\right)$ \\
\end{tabular}} & \multicolumn{3}{|c|}{ THRUST (KgF) } & \multirow{2}{*}{\begin{tabular}{|c} 
RATA-RATA \\
THRUST
\end{tabular}} \\
\hline & & & & & Pengujian 1 & Pengujian 2 & Pengujian 3 & \\
\hline 1500 & 1580 & 1562,0 & 31,4 & 37,5 & 0,74 & 0,66 & 0,56 & 0,65 \\
\hline 3000 & 3130,0 & 3095,0 & 32,4 & 56,9 & 2,64 & 2,67 & 2,69 & 2,67 \\
\hline 4500 & 4566,7 & 4545,2 & 35,2 & 69,3 & 5,73 & 5,76 & 5,75 & 5,75 \\
\hline 6000 & 6183,3 & 6140,8 & 40,3 & 87,2 & 10,62 & 10,59 & 10,58 & 10,60 \\
\hline 7000 & 7056,7 & 7021,7 & 44,1 & 103,7 & 13,70 & 13,50 & 13,60 & 13,60 \\
\hline
\end{tabular}

Tabel 3. Pengujian Engine Dengan Propeller $22 \times 8$ (chord 5cm)

\begin{tabular}{|c|c|c|c|c|c|c|c|c|}
\hline $\begin{array}{c}\text { VARIABEL } \\
\text { RPM }\end{array}$ & \multirow{2}{*}{$\begin{array}{c}\text { RPM GT } \\
\text { POWER }\end{array}$} & $\begin{array}{c}\text { RPM } \\
\text { TACHO }\end{array}$ & T. SPOOL & T.CRANKCASE & \multicolumn{3}{|c|}{ THRUST(KgF) } & $\begin{array}{c}\text { RATA-RATA } \\
\text { THRUST }\end{array}$ \\
\cline { 5 - 9 } & & & $\left.{ }^{\circ} \mathrm{C}\right)$ & $\left({ }^{\circ} \mathrm{C}\right)$ & Pengujan 1 & Pengujian 2 & Pengujian 3 & $(\mathrm{Kgf})$ \\
\hline 1500 & 1548 & 1522,0 & 33,6 & 37,6 & 0,58 & 0,66 & 0,61 & 0,62 \\
\hline 3000 & 3050,0 & 3022,0 & 36,4 & 51,3 & 2,50 & 2,65 & 2,55 & 2,57 \\
\hline 4500 & 4520,0 & 4511,3 & 39,2 & 73,2 & 5,80 & 5,60 & 5,70 & 5,70 \\
\hline 6000 & 6030,0 & 5932,7 & 41,4 & 90,6 & 10,11 & 10,10 & 10,13 & 10,11 \\
\hline 7000 & 7040,0 & 6977,5 & 45,3 & 108,3 & 13,62 & 13,83 & 13,65 & 13,70 \\
\hline
\end{tabular}

\section{Hasil dan Analisis}

Pada bab sebelumnya sudah dijelaskan bahwa tujuan melakukan pengujian ini untuk memvalidasi data alat uji dengan data static thrust calculator dengan propeller wood chord yang berbeda ukuran dan mengetahui konsumsi bahan bakar yang digunakan dalam kondisi lingkungan yang sama. Setelah didapatkan nilai thrust dan Fuel consumption dari pengujian engine test bed, maka bisa dilakukan validasi data dengan mencocokan kembali terhadap datadata yang didapatkan. 
Tabel 4. Hasil Perhitungan Break Specific Fuel consumption

\begin{tabular}{|c|c|c|c|c|c|c|}
\hline \multirow[t]{2}{*}{$\begin{array}{c}\text { VARIABEL } \\
\text { RPM }\end{array}$} & \multirow[t]{2}{*}{$\begin{array}{c}\text { RPM } \\
\text { TACHO }\end{array}$} & $\begin{array}{c}\text { FUEL } \\
\text { CONSUMPT } \\
\text { ION }\end{array}$ & $\begin{array}{c}\text { FUEL FLOW } \\
\text { RATE UJI }\end{array}$ & $\begin{array}{c}\text { FUEL FLOW } \\
\text { RATE UJI }\end{array}$ & BHP(Output) & $B S F C$ \\
\hline & & (g/minute) & $(\mathrm{kg} / \mathrm{hr})$ & $(\mathrm{N} / \mathrm{hr})$ & $\mathrm{kW}$ & (N/kW.hr) \\
\hline 1500 & 1490 & 30 & 1,8 & 17,658 & 0,030 & 588,600 \\
\hline 3000 & 3059 & 35 & 2,1 & 20,601 & 0,267 & 77,157 \\
\hline 4500 & 4535 & 45 & 2,7 & 26,291 & 0,873 & 30,115 \\
\hline 6000 & 6005 & 73 & 4,4 & 42,968 & 2,027 & 21,198 \\
\hline 7000 & 6973 & 112 & 6,7 & 65,727 & 3,174 & 20,708 \\
\hline
\end{tabular}

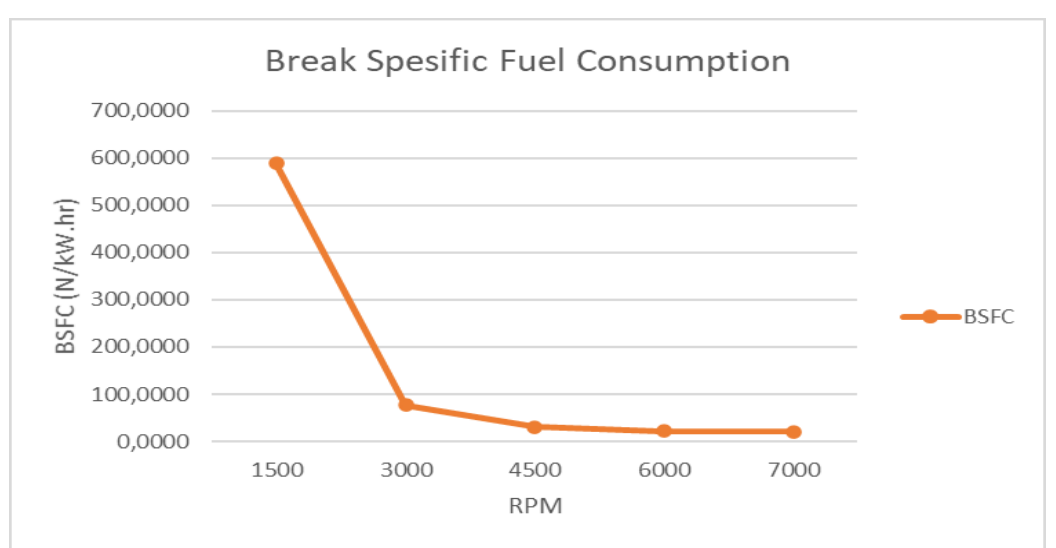

Gambar 2. Hasil Break Specific Fuel consumption

Dari garfik 2 menunjukan bahwa hasil Break Specific Fuel consumption mengalami penurunan. Hal ini dikarenakan semakin meningkat Fuel consumption yang dibutuhkan pada setiap kecepatan putaran (rpm) maka akan semakin rendah nilai dari break specific Fuel consumption, sehingga mesin yang digunakan dapat dikatakan lebih efisiensi dalam penggunaan.Berdasarkan dari hasil pengujian engine test bed yang telah di manufaktur tujuan analisis dan pembahasan ini adalah untuk mevalidasi data uji engine test bed yang dengan cara perbandingan dengan nilai static thrust calculator yang ada. Dari hasil data perbandingan dapat mengambil kesimpulan apakah alat uji ini valid atau tidak untuk mengetahui performa dari sistem propulsi. Perbandingan data pengujian dengan data nilai static thrust calculator sebagai berikut:

Table 5. Data error pada propeller $22 \times 8$ (chord $4,5 \mathrm{~cm})$

\begin{tabular}{|c|c|c|c|c|}
\hline \multirow{2}{*}{$\begin{array}{c}\text { Variabel } \\
\text { Rpm }\end{array}$} & \multirow{2}{*}{$\begin{array}{c}\text { Rpm Alat } \\
\text { Uji }\end{array}$} & $\begin{array}{c}\text { Thrust } \\
\text { Pengujian }\end{array}$ & $\begin{array}{c}\text { Static Thrust } \\
\text { Calculator }\end{array}$ & Margin Error \\
\cline { 3 - 5 } & (Kgf) & (Kgf) & $(\%)$ \\
\hline 1500 & 1580 & 0,65 & 0,70 & 7,143 \\
\hline 3000 & 3130 & 2,67 & 2,78 & 3,957 \\
\hline 4500 & 4566,7 & 5,75 & 5,93 & 3,035 \\
\hline 6000 & 6183,3 & 10,60 & 10,89 & 2,663 \\
\hline 7000 & 7056,7 & 13,60 & 14,18 & 4,090 \\
\hline Rata-Rata & & & & 4,178 \\
\hline
\end{tabular}




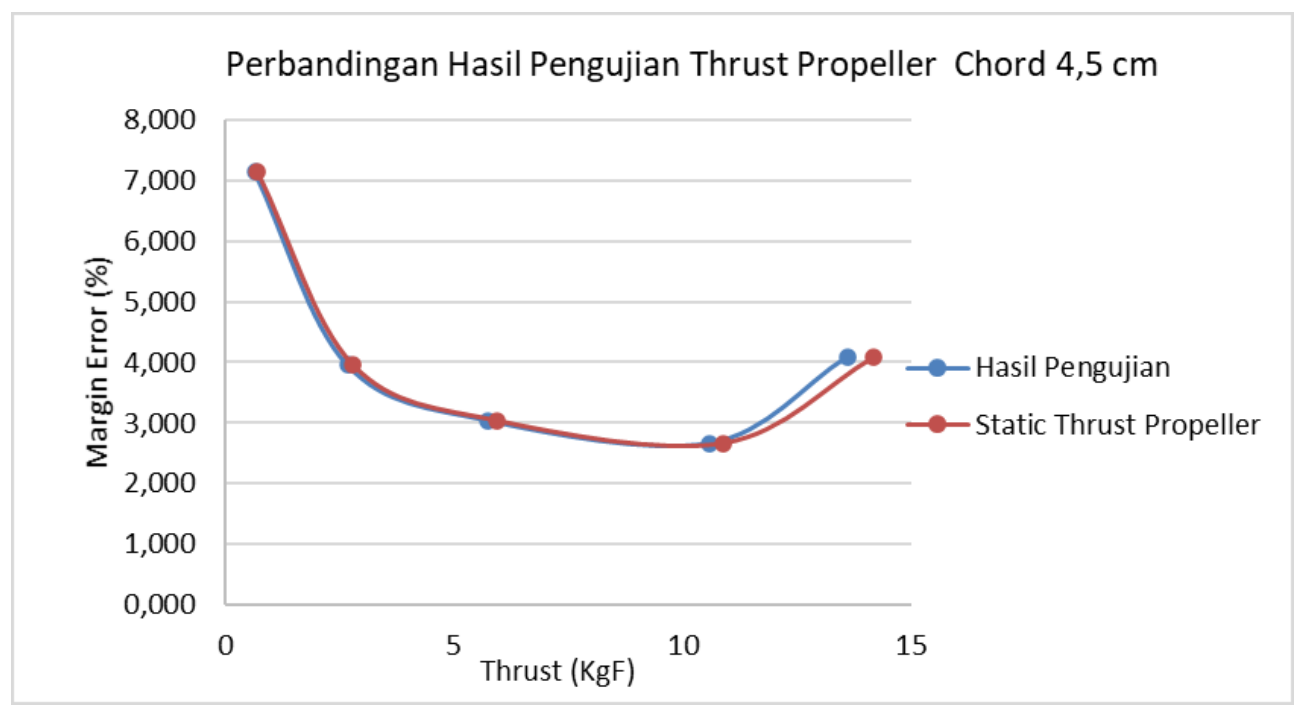

Gambar 3. Grafik Error Thrust Propeller 22×8 (chord 4,5cm)

Perbandingan selanjutnya dilakukan pada propeller $22 \times 8($ chord $5 \mathrm{~cm})$ pada tabel 6 .

Table 6. Data error pada propeller $22 \times 8$ (chord $5 \mathrm{~cm})$

\begin{tabular}{|c|c|c|c|c|}
\hline $\begin{array}{c}\text { Variabel } \\
\text { Rpm }\end{array}$ & $\begin{array}{c}\text { Rpm } \\
\text { Alat Uji }\end{array}$ & Thrust Pengujian & $\begin{array}{c}\text { Static Thrust } \\
\text { Calculator }\end{array}$ & Margin Error \\
\cline { 3 - 5 } & 1548 & $(\mathrm{Kgf})$ & $(\mathrm{Kgf})$ & $(\%)$ \\
\hline 1500 & 0,62 & 0,68 & 8,824 \\
\hline 3000 & 3050 & 2,57 & 2,64 & 2,652 \\
\hline 4500 & 4520 & 5,70 & 5,81 & 1,893 \\
\hline 6000 & 6030 & 10,11 & 10,35 & 2,391 \\
\hline 7000 & 7040 & 13,70 & 14,11 & 2,906 \\
\hline Rata-Rata & & & & 3,719 \\
\hline
\end{tabular}

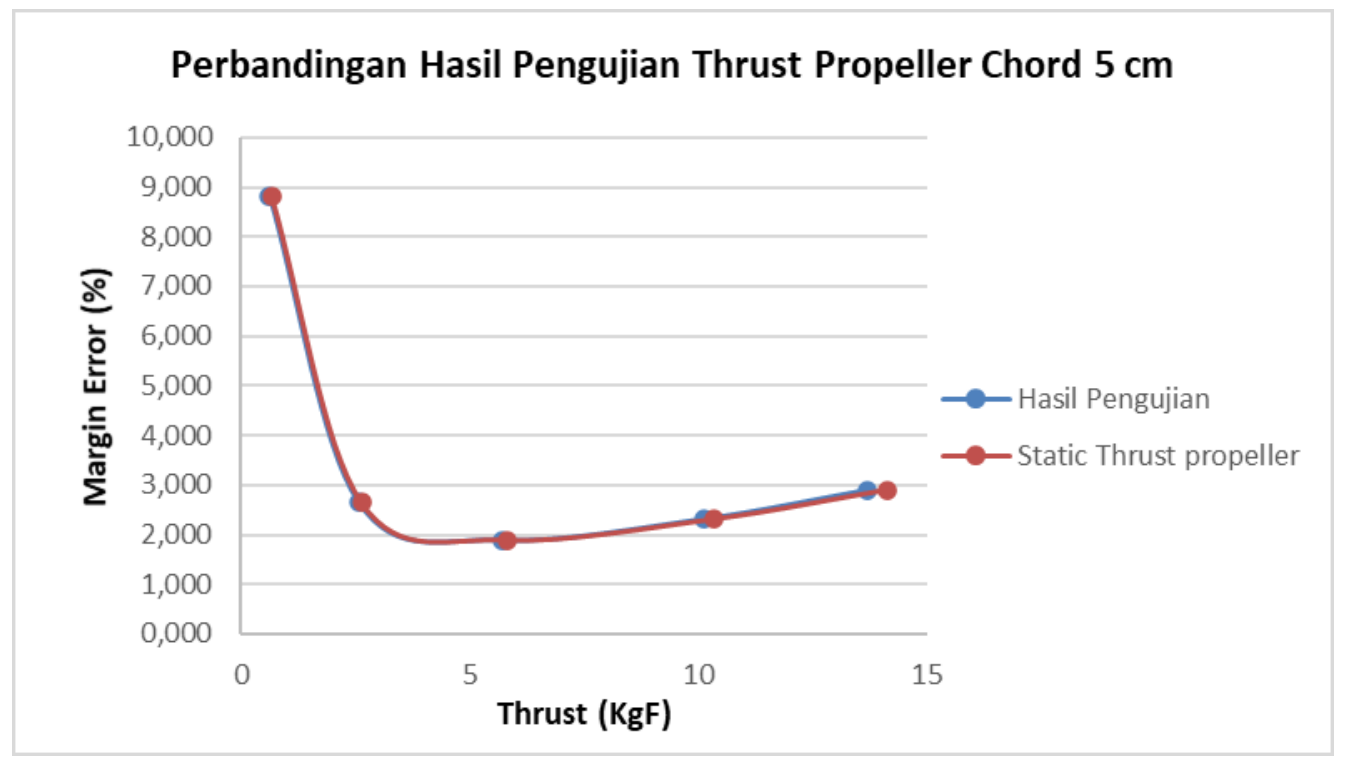

Gambar 4. Grafik Error Thrust Propeller 22×8 (chord 5cm) 
Dari hasil perbandingan error pada alat uji dengan propeller $22 \times 8$ (chord $4,5 \mathrm{~cm}$ ) memiliki perbedaan error maksimum 7,143\% dan minimum 2,663\%, sedangkan rata-rata error sebesar 4,178 \%. Propeller 22 $\times 8$ (chord $5 \mathrm{~cm}$ ) memiliki perbedaan error maksimum 8,824 \% dan minimum error $1,893 \%$, sedangkan rata-rata error sebesar 3,719 \%.

\section{Kesimpulan}

Telah dilakukan perhitungan dan pengujian gaya dorong engine dle-55cc. dari hasil uji engine yang diperoleh kemudian divalidasi dengan membandingkan nilai static thrust calculator dan data pengujian alat uji yang telah dilakukan, kemudian mencari nilai konsumsi bahan bakar yang digunakan. Hasil thrust yang terukur dibandingkan dengan nilai static thrust calculator didapat perbedaan rata-rata, dari perbandingan error pada alat uji, propeller $22 \times 8$ (chord 4,5cm) ini didapat rata-rata error sebesar $4,178 \%$. Sedangkan propeller $22 \times 8$ (chord $5 \mathrm{~cm}$ ) error yang dihasilkan sebesar 3,719 \% dan dari nilai konsumsi bahan bakar yang didapat menghasilkan 588,600-20,708 (N/kW.hr) hal ini menunjukan tingkat penurunan yang baik, sehingga mesin yang digunakan lebih efisiensi dalam penggunaan. Dari hasil pengujian dapat dikatakan bahwa engine test bed tersebut mempunyai akurasi dan dapat menghasilkan performa engine yang baik untuk digunakan sebagai alat pengujian maupun pembelajaran lainnya.

\section{DAFTAR PUSTAKA}

[1] Arismunandar, W. 2002. "Pengantar Turbin Gas dan Motor Propulsi". Bandung: ITB.

[2] De Sousa, Andre. 2017. "Development of a Test Bench for UAV Propulsion System Characterisation". Portugal: Tecnicio Lisboa.

[3] M. P. Groover. 2010. "Fudamentals of Modern manufacturing: Materials, Processes, and System", Edisi 4.

[4] Arifin, S.R., D. Anggraeni, A. Rahmadi, E. Sumarna, 2014. "Engine and Propeller Selection for Propulsion System LAPAN Surveillance UAV-05 using Static Thrust Calculation and Test, Proceedings ISAST". Indonesia. Vol.II, 978-602-71833-0-8: 4150 .

[5] Gabriel, S., 2014. "Propeller Static \& Dynamic Thrust Calculation", https://www.electricrcaircraftguy.com, diakses pada September 2017.

[6] Basyirun, Winarno, \& Karnowo. (2008). Buku Ajar Mesin Konversi Energi. Semarang : Universitas Negeri Semarang. 